\title{
To the Miracle on the Han
}

Written by: Donald Johnston, former Secretary-General of the OECD (1996-2006)

Last update: 4 April 2017

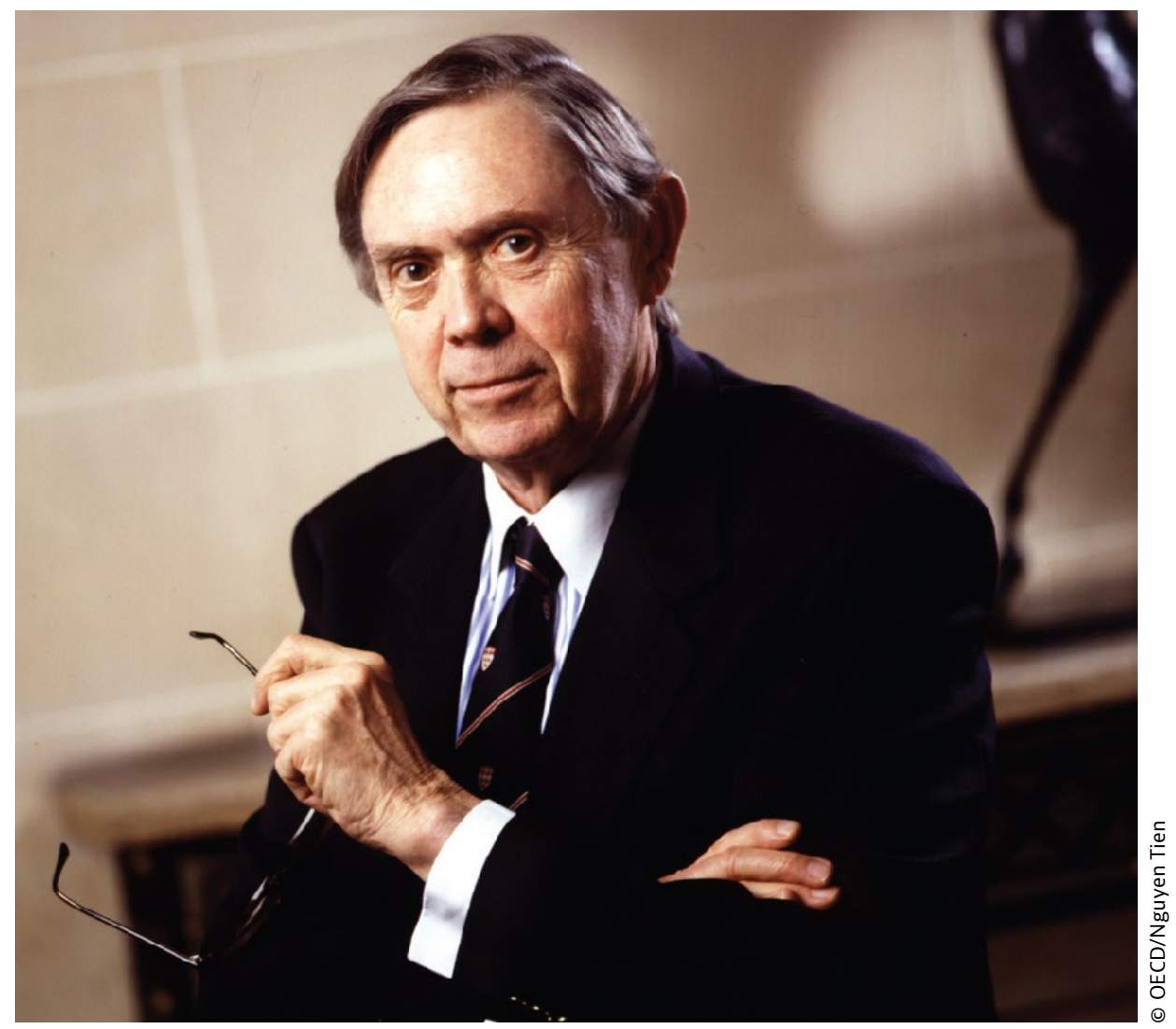

During my tenure as secretary-general of the OECD, few events gave me as much pleasure as welcoming Korea as a member in the autumn of 1996. At the end of hostilities in 1953 South Korea was one of the poorest countries in the world, having emerged from a bitter conflict, which left much of it in ashes. The toll in human lives was enormous, with as many as 217,000 Korean soldiers and 100,000 civilians killed, along with tens of thousands of UN force soldiers. It seemed impossible that in less than $\mathbf{5 0}$ years Korea had rebuilt its physical and human infrastructure and was ready to join the small group of developed countries known by some as the "rich man's club".

This extraordinary progress on every front became known as the Miracle on the Han, the beautiful river that runs through Seoul on its way to the sea. President Kim Young-sam was in office in 1996 and he was soon to be succeeded by Kim 
Dae-jung, who assumed office only to be faced with the worst economic downturn since the end of hostilities. Korea suddenly found itself as a victim of the contagious Asian financial crisis, which had its origins in Thailand just months before.

The impact of the crisis beginning in late 1997 came under the mandate of Kim Dae-jung. Even economists at the OECD believed that the Miracle on the Han was at an end! The leadership of President Kim Dae-jung and his regular messages to the Korean people were instrumental in surmounting the crisis as no other country has done before nor since. In fact, Korea went from a near $6 \%$ economic contraction to over $11 \%$ growth in some 18 months!

During that period the president invited me regularly to Korea to speak, meet journalists and reinforce his messages. They were Donald Johnston, former Secretary-General of the OECD (1996-2006) messages, not of despair; yes, of considerable sacrifice, but suggesting a prosperous future. Since 1998 Korea's GDP has more than doubled in real terms, and now amounts to US\$1.3 trillion!

During the past 20 years I have visited Korea several times a year. Indeed, after stepping down from the OECD in 2006 my regular visits have continued.

In many ways the Korea I know is unique. Of course it is physically beautiful-and I have yet to enjoy all that beauty- mountains, plains, beaches and the wonderful Jeju Island, which I have visited on several occasions. But quite a number of countries have such physical marvels. They do not make Korea unique. It is the people who make Korea unique.

Unlike many OECD member countries, Korea does not benefit from an abundance of natural resources. It has engineered its comparative advantages relying on imported materials and energy, and competing with quality exports in world markets.

I believe this Miracle on the Han, which showed its resilience as it recovered from the Asian financial crisis, is a product of the education levels of the Korean people.

Their collective response to the financial crisis of the late 1990s also demonstrates this. They understood the messages from President Kim Dae-jung, knew what had to be done, and did it.

This thirst for education seems rooted in the culture of Korea. When I read the diaries of the Dutch sailor Hendrik Hamel, a captive for many years in Korea in the 17th century, he described this characteristic as follows:

"The nobility and well-to-do people give their children a good education. They take tutors in their service to teach them how to read and write, skills to which this nation is much inclined." 
Good education has been central to Korea's success and it seems that North Koreans have also inherited that trait, with a reported national literacy rate of $99 \%$ for those over 15 years of age. That is very encouraging as the peninsula moves, hopefully, towards unification.

There is good reason to celebrate this 20th anniversary. Korea has set an example for other emerging market economies to follow. It has even moved from being a recipient of development aid to being a donor and a member of the OECD Development Assistance Committee.

The great economist, John Maynard Keynes, advised that one should examine the present, in light of the past, for the purposes of the future. When one does that, it is impossible not to be very optimistic about the future of Korea and its people.

For more on Donald Johnston, see http://oe.cd/1lJ 